\title{
Effect of Minor Milk Proteins in Chymosin Separated Whey and Casein Fractions on Cheese Yield as Determined by Proteomics and Multivariate Data Analysis
}

\author{
A. Wedholm, ${ }^{* 1}$ H. S. Møller, † A. Stensballe,‡ H. Lindmark-Månsson,§ A. H. Karlsson,\# R. Andersson, ${ }^{*}$ A. \\ Andrén, ${ }^{*}$ and L. B. Larsen† \\ *Department of Food Science, Uppsala BioCenter, Swedish University of Agricultural Sciences, SE-750 07 Uppsala, Sweden \\ †Department of Food Science, Faculty of Agricultural Sciences, University of Aarhus, DK-8830 Tjele, Denmark \\ $\ddagger$ University of Aalborg, Sohngaardsholmsvej, DK-9000 Aalborg, Denmark \\ $\S$ Swedish Dairy Association, SE-223 70 Lund, Sweden \\ \#Department of Food Science, Faculty of Life Sciences, University of Copenhagen, DK-1958 Frederiksberg C, Denmark
}

\begin{abstract}
The objective of this work was to find regressions between minor milk proteins or protein fragments in the casein or sweet whey fraction and cheese yield because the effect of major milk proteins was evaluated in a previous study. Proteomic methods involving 2-dimensional gel electrophoresis and mass spectrometry in combination with multivariate data analysis were used to study the effect of variations in milk protein composition in chymosin separated whey and casein fractions on cheese yield. By mass spectrometry, a range of proteins significant for the cheese yield was identified. Among others, a C-terminal fragment of B-casein had a positive effect on the cheese yield expressed as grams of cheese per $100 \mathrm{~g}$ of milk, whereas several other minor fragments of $6-, \alpha_{\mathrm{s} 1^{-}}$, and $\alpha_{\mathrm{s} 2^{-}}$-casein had positive effects on the transfer of protein from milk to cheese. However, the individual effect of each identified protein was relatively low. Therefore, further studies of the relations between different proteins/peptides in the rennet casein or sweet whey fractions and cheese yield are needed for advanced understanding and prediction of cheese yield.
\end{abstract}

Key words: rennet casein, sweet whey protein, proteomics, protein transition number

\section{INTRODUCTION}

Within the dairy industry it is desirable to control the technological properties of milk to achieve optimal cheese yield and quality. To improve cheese yield, it is crucial to increase the amount of protein that is transferred from cheese milk into the cheese curd. Further-

\footnotetext{
Received January 16, 2008.

Accepted May 19, 2008.

${ }^{1}$ Corresponding author: Anna.Wedholm@lmv.slu.se
}

more, the milk proteins, especially the caseins, contribute to the cheese structure and texture. Accordingly, in many countries, milk farmers are compensated for high amounts of milk protein to obtain higher cheese yield and quality. However, poor cheese-making properties in spite of high milk protein concentrations have been reported (Ikonen et al., 1999), and other significant variables have been suggested. Among them are concentrations (Marziali and Ng-Kwai-Hang, 1986; Wedholm et al., 2006) and genetic variants (Ng-Kwai-Hang, 1998) of individual caseins. Significant variables for the technological quality of milk have also been found within the whey protein fraction. It is documented that the $\mathrm{B}$ allele of B-LG is associated with greater cheese yield than the A allele (Marziali and Ng-Kwai-Hang, 1986; Schaar et al., 1985; Wedholm et al., 2006), which is due to the positive correlation between casein number and B-LG B (Schaar et al., 1985; van den Berg et al., 1992; Lundén et al., 1997).

In addition to genetic variation among milk proteins there are several posttranslational modifications such as phosphorylation, glycosylation, disulphide-bond formation, and proteolysis that occur among the milk proteins. The use of 2-dimensional gel electrophoresis (2-DGE) facilitates the separation of modification products with similar molecular masses because the proteins are not just separated according to molecular weight, but also in a second dimension according to their isoelectric points. Earlier studies by LindmarkMånsson et al. (2005) showed that 2-DGE is a useful tool to detect variations in milk protein composition, and it is a widely used method within milk proteomics (O'Donnell et al., 2004). Using 2-DGE and matrixassisted laser desorption/ionization time-of-flight (MALDI-TOF), Galvani et al. (2000, 2001) identified the major caseins and whey proteins, including their isoforms, in commercial bovine milk and in a milk powder. Holland et al. (2004) were able to detect 10 
isoforms of $\mathrm{k}-\mathrm{CN}$ from a cow heterozygous for the A and $\mathrm{B}$ variants of $\mathrm{K}-\mathrm{CN}$, by 2 -DGE and mass spectrometry detection. Several low-abundance bovine milk proteins have also been identified in whey and skim milk fractions by proteomic methods (Yamada et al., 2002; Smolenski et al., 2002; Fong et al., 2008). In a previous study the 2-DGE technique in combination with MS detection and multivariate data analysis was used to study the relation between milk protein composition and milk yield (Larsen et al., 2007). The same method has also been used to link proteomic profiles and quality parameters in meat (Jessen et al., 2002) and in plant science (Gottlieb et al., 2004).

During renneting, most of the whey proteins end up in the sweet whey fraction and the caseins in the rennet casein fraction. However, the separation is never complete which is believed to have consequences for the cheese yield. Earlier, when Wedholm et al. (2006) analyzed the effect of the major milk protein composition on the cheese-making properties, it was confirmed that the casein number (casein in relation to total protein) in milk had a significantly positive effect on the transfer of proteins from milk to cheese (i.e., the protein transition number). In the same study, the significant effects of the individual major caseins ( $\alpha-,, B-$, and $\mathrm{K}$-casein) on cheese yield were demonstrated. The subject of this study was to evaluate these findings further by analyzing minor milk proteins or protein fragments in the whey and casein fractions of chymosin-treated milk and relate it to cheese yield. By use of proteomics in combination with multivariate regression, this work aimed to study the effect of variations in whey and casein composition, as separated by chymosin, between individual cows on the yield of low-fat model cheeses.

\section{MATERIALS AND METHODS}

\section{Milk Sampling}

Evening whole milk (10 L) from 43 Danish Holstein Friesian (SDM) cows were sampled at the experimental herd at the Faculty of Agricultural Sciences, University of Aarhus (former Danish Institute of Agricultural Sciences) as described earlier (Wedholm et al., 2006). The cows were housed in tie stalls and fed a total mixed ratio of normal energy density. All cows included in the study were healthy and milked twice a day. The cows were selected to represent a balanced material of varying levels of total milk protein concentration (from low to high). Total protein and casein concentrations of the samples were determined by a Milkoscan FT 6000 (Foss Electric, Hillerød, Denmark) and were in the range from 2.69 to $4.21 \mathrm{~g} / \mathrm{L}$ and 2.05 to $3.30 \mathrm{~g} / \mathrm{L}$, respectively.
Table 1. Means and SD of cheese yield (expressed in 2 ways)

\begin{tabular}{lcc}
\hline Item & $\begin{array}{c}\text { g of cheese per } \\
100 \mathrm{~g} \text { of milk }\end{array}$ & $\begin{array}{c}\mathrm{g} \text { of dry cheese solids per } \\
100 \mathrm{~g} \text { of milk protein }\end{array}$ \\
\hline Mean & 7.90 & 91.57 \\
SD & 1.23 & 10.45 \\
df & 42.00 & $35.00^{1}$ \\
Minimum & 5.70 & 67.90 \\
Maximum & 10.20 & 129.68 \\
\hline
\end{tabular}

${ }^{1}$ Number of observations reduced because of missing data.

\section{Cheese Making and Determination of Cheese Yield}

Low-fat model cheeses were produced from skimmed milk to reduce the number of variables influencing cheese yield. After $2 \mathrm{~d}$ of cold storage $\left(4^{\circ} \mathrm{C}\right)$, individual milk samples were preheated to $40^{\circ} \mathrm{C}$, defatted, and then heated in a pilot plate heating apparatus $\left(72^{\circ} \mathrm{C}\right.$ for $15 \mathrm{~s}$ ) as described by Allmere et al. (1998). Four liters of skimmed milk was inoculated with a commercial starter culture $(0.1 \mathrm{~g} / \mathrm{L}$ of Lactobacillus helveticus 174 and $0.1 \mathrm{~g} / \mathrm{L}$ of Probat 404, Danisco, Sweden) and incubated at $30^{\circ} \mathrm{C}$ for $30 \mathrm{~min}$. This was followed by addition of chymosin $(1.25 \mathrm{~mL} / \mathrm{L}$, Chy-max Plus with 190 International Milk Clotting Units/mL, Chr Hansen A/S, Copenhagen, Denmark) and gentle stirring. After 30 min at $30^{\circ} \mathrm{C}$, the gel formed was cut into 2 -cm cubes. To allow syneresis, the curd was incubated at $50^{\circ} \mathrm{C}$ for another 30 min during gentle stirring. The whey was removed and the curd was pressed $\left(0.04 \mathrm{~kg} / \mathrm{cm}^{2}\right)$ during $20 \mathrm{~h}$ at room temperature. After $2 \mathrm{wk}$ of storage at $10^{\circ} \mathrm{C}$, the cheeses were weighed to obtain the yield. To obtain dry weight from individual cheeses, 2 to 3 $\mathrm{g}$ was taken from the interior of the cheeses, grated, and mixed with a fixed amount of sand. These cheese samples were incubated at $105^{\circ} \mathrm{C}$ overnight and then placed in a dessicator for $1 \mathrm{~h}$ before weighing. The cheese yield was expressed in 2 ways: in relation to amount of cheese milk used (as g of cheese per $100 \mathrm{~g}$ of milk) or as a sort of protein transition number (as $\mathrm{g}$ of dry cheese solids per $100 \mathrm{~g}$ of milk protein), as recommended by Emmons (1993). Means and standard deviations of cheese yield obtained from the individual milk samples are presented in Table 1.

\section{Fractionation of Samples for 2-DGE}

Milk samples for 2-DGE analysis were fractionated separately from the cheese making trial to avoid the influence of the starter culture growth. An aliquot of each individual milk sample was skimmed twice at 3,000 $\times \mathrm{g}$ for $10 \mathrm{~min}$. The skimmed milk was preheated at $30^{\circ} \mathrm{C}$ for $30 \mathrm{~min}$ and fractionated into casein and whey by addition of chymosin $(2 \mathrm{~mL} / \mathrm{L})$. A higher concentration 
was needed for this separation because of the higher $\mathrm{pH}$ in absence of starter culture. The samples were incubated at $30^{\circ} \mathrm{C}$ for $30 \mathrm{~min}$ and then centrifuged at $1,000 \times g$ for $10 \mathrm{~min}$ at $5^{\circ} \mathrm{C}$ to separate sweet whey and rennet casein, followed by recovery of the sweet whey fraction. This fraction is subsequently denoted as proteins in the whey fraction (PWF). The rennet casein was washed twice in cold MP-water (USF Elga Maxima system, Bucks, UK) and centrifuged at $1,000 \times g$ for 5 $\min$ at $5^{\circ} \mathrm{C}$. The casein fraction was dissolved in $0.1 \mathrm{M}$ tri-sodium citrate buffer, $\mathrm{pH} 8.9$, to the original milk volume and stored at $-20^{\circ} \mathrm{C}$ until further use. This casein fraction was subsequently denoted as proteins in the casein fraction $(\mathbf{P C F})$.

\section{Two-Dimensional Gel Electrophoresis}

The rennet sweet whey and rennet casein fractions were analyzed on separate 2-DGE gel sets consisting each of 43 gels. The first dimension of protein separation was carried out in immobilized 11-cm IPG strips ( $\mathrm{pH} 4$ to 7, BioRad, Hercules, CA), whereas 8 to $16 \%$ gradient Criterion gels (BioRad) were used for the second dimension. For analytical gels subjected to image analysis a volume of the sweet whey protein fraction corresponding to $50 \mathrm{\mu g}$ was applied, whereas for analysis of rennet caseins $40 \mu \mathrm{g}$ was analyzed. For preparative gels used for MS analysis a volume corresponding to $370 \mu \mathrm{g}$ of sweet whey protein sample or $200 \mu \mathrm{g}$ of rennet caseins was applied. The total protein and whey protein contents were based on the Milkoscan determinations. The desired amount of sample was dissolved at $1: 10 \mathrm{vol} / \mathrm{vol}$ in denaturing buffer consisting of 6 $M$ urea, $2 M$ thiourea, $1.5 \%$ (wt/vol) pharmalyte (GE Healthcare, Uppsala, Sweden), 0.8\% (wt/vol) 3-[(3-cholamidopropyl) dimethylammonio]-1-propansulfonate, CHAPS (Applichem, Darmstadt, Germany) 1\% (wt/ vol) dithioerythritol in water and incubated for $2 \mathrm{~h}$ at room temperature. The reduced proteins were further diluted in a rehydration buffer to a final volume of 185 $\mu \mathrm{L}$. The rehydration buffer consisted of the same substrates, in same concentrations as the reducing buffer, but with pharmalyte $(5 \mu \mathrm{L} / \mathrm{mL})$ instead of $1 \%$ dithioerythritol. Running conditions for the 2-DGE gels were essentially as described by Lametsch and Bendixen (2002). Analytical gels were silver-stained according to Lametsch and Bendixen (2002), whereas preparative gels for MS were stained according to Shevchenko et al. (1996).

\section{Image Analysis}

The 2-DGE gels were photographed by a Vilber Lourmat digital camera (ImageHouse, Copenhagen, Denmark) equipped with Gel Pro analyzer software.
The gel spots were detected and quantified with ImageMaster 2D platinum software (Amersham Pharmacia Biotech, Uppsala, Sweden). After initial analysis using automated spot detection and segmentation, all images were manually checked and the spots were matched by comparing the relative positions of the individual spots on each gel. The spots were quantified by adding the pixel intensities within the spot boundary, and the spot volumes were calculated. To overcome gel-to-gel variations in spot intensities due to technical variations related, for example, to the staining procedure, the relative spot volumes were calculated for each separate spot on each gel, and these values were used in further data analysis.

\section{In Gel Digestion, Desalting, and Concentration of Protein Spots}

Protein spots of significance were subjected to in-gel digestion by addition of trypsin essentially as described by Jensen et al. (1998). Custom-made chromatographic columns were used for desalting and concentration of the peptide mixture from each spot before MS analysis as described by Lametsch et al. (2002). For MALDI-TOF analysis the peptides were eluted in $0.5 \mu \mathrm{L}$ of matrix solution (15 to $20 \mathrm{~g} / \mathrm{L}$ of a-cyano-4-hydroxycinnamic acid; Sigma Aldrich, St. Louis, MO, in 70\% acetonitrile) directly onto the MALDI target plate (Bruker Daltonics $\mathrm{GmbH}$, Bremen, Germany). For liquid chromatography quadropole time-of-flight (Q-TOF) MS analysis the peptides were eluted in $0.5 \mu \mathrm{L} 70 \%$ acetonitrile.

\section{Identification of Milk Proteins by MALDI-TOF Mass Spectrometry}

Mass spectra were obtained using a Bruker Ultraflex MALDI-TOF tandem mass spectrometer in reflection mode. A peptide calibration standard $(0.2 \mu \mathrm{L}$, Bruker Daltonics $\mathrm{GmbH}$ ) containing 7 standard peptides ranging in molecular masses from $1,046.54$ to $3,147.47 \mathrm{Da}$ was spotted separately onto the MALDI target plate. The ion accelerating voltage was $25 \mathrm{kV}$ with a delay time of $40 \mathrm{~ns}$. The laser frequency was $50 \mathrm{~Hz}$ and 200 laser shots were accumulated for each spectrum. For tandem mass spectrometry (MS/MS) lift mode the ion accelerating voltage was $19 \mathrm{kV}$. Proteins were identified by peptide mass fingerprinting by mass searches in the database Swiss Prot (Swiss Institute of Bioinformatics, Geneva, Switzerland), or by fractionation of their parent ions in MS/MS mode followed by mass searches in the database. For both applications the MS/MS ion search program Mascot (Matrix Science, Boston, MA) was used. In this program the experimental mass value, obtained from MS or MS/MS, is compared with 
calculated peptide masses from a database. A scoring algorithm is used to identify the closest match. Significant protein identifications (protein scores above 62, $P$ $<0.05$ ) were reported and manually verified.

\section{Identification of Milk Proteins by Q-TOF Mass Spectrometry}

Automated liquid chromatography electrospray ionization MS/MS was performed using a hybrid Q-TOF mass spectrometer (Bruker Daltronics) and an Ultimate nano-HPLC system (LC Packings, Amsterdam, the Netherlands) mounted with a vented-column setup. Reversed phase columns (pre-column $2 \mathrm{~cm}, 75 \mu \mathrm{m} \mathrm{id}$; separation column $12 \mathrm{~cm}, 50 \mu \mathrm{m}$ internal diameter)

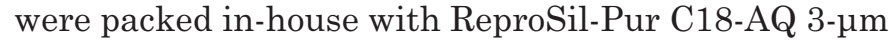
resin (Dr. Maisch GmbH, Ammer-Buch-Entringen, Germany) using a high-pressure vessel. Aliquots of the tryptic peptides corresponding to $25 \%$ of each gel spot were injected onto the pre-column with a flow rate of 3 $\mu \mathrm{L} / \mathrm{min}$ and subsequently eluted at $175 \mathrm{~nL} / \mathrm{min}$ using a 35 min gradient of 5 to $40 \%$ acetonitrile in $0.6 \%$ acetic acid and $0.005 \%$ heptafluorobutyric acid. The mass spectrometer was operated in data-dependent mode to automatically switch between MS and MS/MS acquisition selecting the 3 most abundant precursor ions. The tandem MS data was deconvoluted and deisotoped and exported in a mascot generic format before database searching. Protein homologs were identified by use of an in-house Mascot database search engine using the SwissProt database or the NCBInr database (May 2007). Tandem MS search parameters had a mass accuracy of $\pm 0.025 \mathrm{Da}$; methionine oxidation, serine and threonine phosphorylation, and carbamidomethyl allowed as variable modifications. Cleavage specificity was specified as semitryptic to validate any sequence processing. Results from the automatic database search were evaluated in accordance with the Paris Publication Guidelines (2007). Significant protein identifications (protein scores above 75, minimum 2 unique peptides identified, $P<0.05$ ) were reported and manually verified.

\section{Partial Least Squares Regression Analysis}

Partial least squares regression 1 (PLS-1) analysis was carried out using the software The Unscrambler ver. 9.0 (CAMO ASA, Oslo, Norway) to study the effect of 2-DGE spot variations on the response Y-variables, cheese yield expressed as grams of cheese per $100 \mathrm{~g}$ of milk or as grams of dry cheese solids per $100 \mathrm{~g}$ of milk protein. The rennet casein and sweet whey protein fractions on the 2-DGE gels were analyzed separately and composed the regressors (X-variables) in the PLS-
1 model. When analyzing the effect of the sweet whey protein composition on the 2 types of cheese yield the relative volume of each spot, as determined by image analysis, was used as continuous X-parameters, whereas discriminant regressors were used in the model for analysis of the effect of rennet casein composition on the same traits. In the discriminant model, the protein spot in the sample was denoted by a binary variable: 1 if present or 0 if absent, as indicated by image analysis (Radzikowski et al., 2002). The background for application of a discriminant model for the analysis of the spots in the rennet casein fraction is further discussed in the Results and Discussion section. Standardized (centered: $\mu=0$, and normalized: $1 / \mathrm{SD}$ ) variables and full cross validation were used. Spots contributing little to the model were removed by jack-knifing (Martens and Martens, 2000) until an optimally calibrated and validated model was achieved (i.e., when the calibration and validation curves became parallel). The optimal number of principal components and significant $(P$ $<0.05$ ) regression coefficients were identified using the uncertainty test.

\section{RESULTS AND DISCUSSION}

\section{2-DGE Separation and MS-Identification of Milk Proteins}

To be able to relate the distribution of casein and whey proteins between the 2 fractions to the cheese yield, the skimmed milk samples were fractionated by addition of chymosin. The rennet casein and sweet whey fractions were subsequently separately analyzed. Examples of 2-DGE separations of proteins in the casein fraction $(\mathrm{PCF})$ and in the sweet whey fraction (PWF) are shown in Figures 1 and 2, respectively. It is evident, that due to the similarities in molecular masses and $\mathrm{pI}$ values of the caseins, these were more poorly separated than the whey proteins. The positions of major individual milk proteins in the 2-DGE gels are indicated. The identifications of major caseins and whey proteins were carried out by MALDI-TOF MS by peptide mass fingerprinting, by MS/MS analysis of peptides generated from major proteins excised from the gels (results not shown) or by comparison with earlier published 2-DGE pictures of the caseins (Holland et al., 2004) and whey proteins (Larsen et al., 2007; Fong et al., 2008), and are indicated in Figures 1 and 2 . The major proteins identified in the rennet casein fraction included $B-C N, a_{s^{1}}-\mathrm{CN}$, and $\alpha_{\mathrm{s}_{2}}-\mathrm{CN}$ monomers. The $a_{\mathrm{s} 2}$ CN dimer was not seen due to the inclusion of reducing agent in the sample buffer. Due to the addition of chymosin, most of the $\mathrm{k}-\mathrm{CN}$ was cleaved into para-k-CN and caseinomacropeptide (CMP). Para-k- 


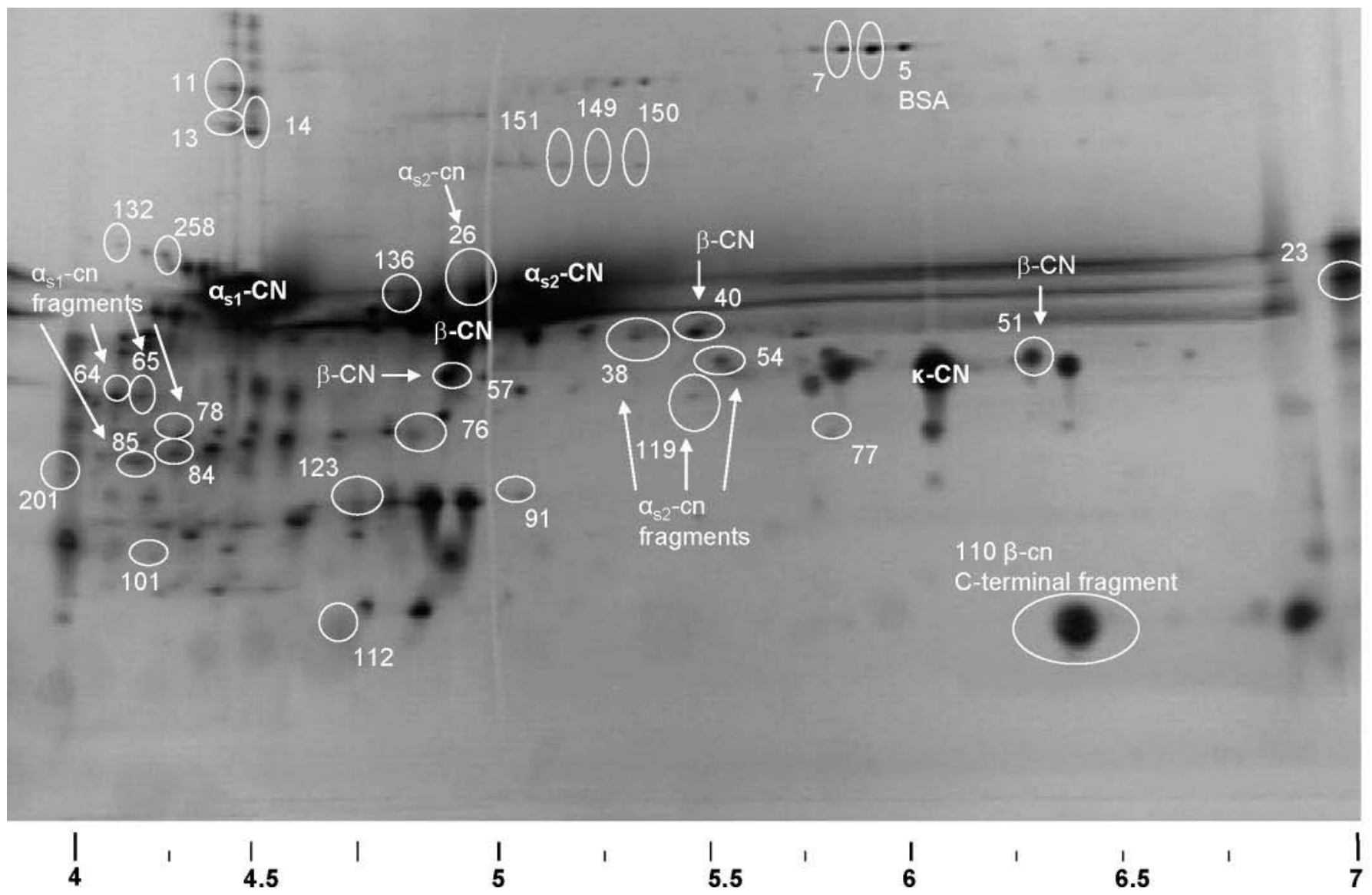

Figure 1. Two-dimensional gel electrophoresis of proteins in the rennet casein fraction (PCF) isolated from 1 individual cow. Proteins with a significant influence on cheese yield (expressed as $\mathrm{g}$ of cheese per $100 \mathrm{~g}$ of milk or as g of dry cheese solids per $100 \mathrm{~g}$ of milk protein) are marked with white circles, and indicated by their ID numbers from the image analysis. Protein spots identified by mass spectrometry are further indicated by names. The positions of other major proteins are indicated by protein names given in bold face.

$\mathrm{CN}$ is expected to be associated with the rennet casein fraction, whereas the CMP ends up in the sweet whey fraction. The hydrophobic para-k-CN (residue 1 to 105) has a molecular mass of approximately $13 \mathrm{kDa}$, whereas the polar, negatively charged CMP (residue 106 to 169 ) has a mass of 8 to $10 \mathrm{kDa}$, depending on the extent of glycosylation (Fox, 1988). Due to the low molecular mass of CMP, this fragment is not expected to be retained in the 2-DGE gels used. The position of para-k-CN was not identified in this study and may be focused outside the pI-range used here for the gels. However, the importance of para-k-CN for the transfer of protein from milk to cheese has been documented earlier and was suggested to be slightly better for prediction of cheese yield than simply the casein concentration (Emmons et al., 2003). Therefore, in the present study we focused on the significance of fragments apart from para-k-CN that could be related to cheese yield. In spite of the addition of chymosin, some intact $\mathrm{k}-\mathrm{CN}$ spots (according to the molecular mass) were present in the casein fraction, in addition to some remnants of BSA (Figure 1). Among PWF, the positions of the following major proteins were identified by MALDI-TOF MS: B-LG, a-LA, BSA, proteose peptone component 3, and lactoferrin (Figure 2). The protein a-LA was seen to separate into various forms with different $\mathrm{pI}$ values. This could be due to the presence of different glycosylated forms of the molecule (Slangen and Visser, 1999) but was not further studied. Furthermore, the position of the added chymosin was identified by MALDI-TOF MS. During renneting, most of the chymosin ends up in the whey fraction. However, the proportion that is retained in the rennet casein varies between cheese varieties and has an influence on the cheese texture and flavor (Bansal et al., 2007).

\section{PLS-1 Analyses}

The PLS is a good tool for analysis of complex data sets with a large number of $\mathrm{x}$-variables that covariate 


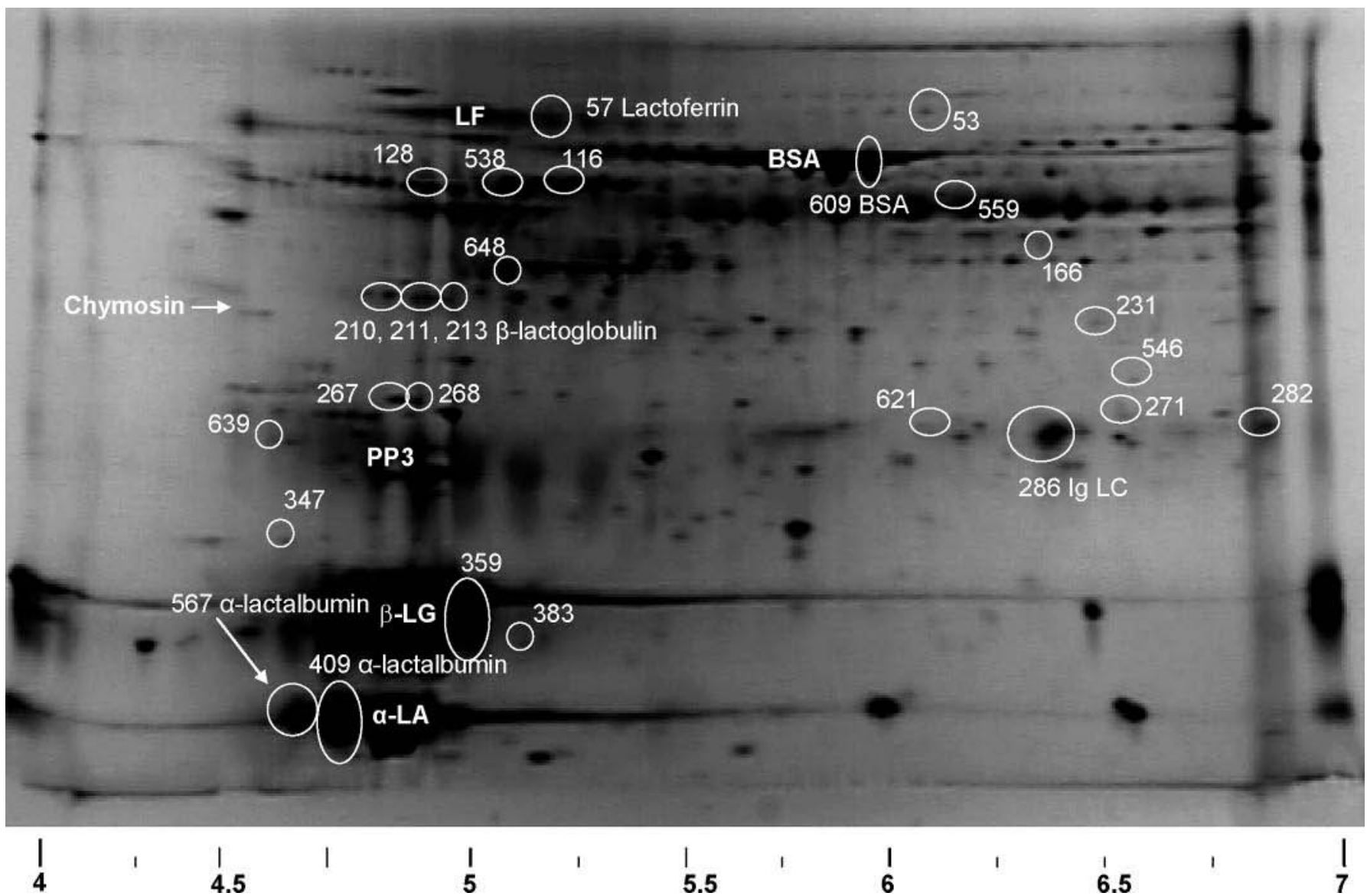

Figure 2. Two-dimensional gel electrophoresis of proteins in the sweet whey fraction (PWF) prepared from 1 individual cow. Proteins with a significant influence on cheese yield (expressed as $\mathrm{g}$ of cheese/100 $\mathrm{g}$ of milk or as $\mathrm{g}$ of dry cheese solids/100 g of milk protein) are marked with white circles and indicated by their ID numbers from the image analysis. Protein spots identified by mass spectrometry are further indicated by names. The positions of other major proteins are indicated by protein names given in bold face. PP3 = proteose peptone component 3; Ig LC = immunoglobulin G $\lambda$-light chain; $\mathrm{LF}=$ lactoferrin.

and has earlier been applied in other proteomic studies (Jessen et al., 2002; Gottlieb et al., 2004). In this study, a PLS-1 model was used to analyze the effects of variations in $\mathrm{PCF}$ and $\mathrm{PWF}$ on the cheese yield. In the case of analyzing the regressions between PCF and cheese yield, a binary annotation of the spots, instead of continuous values of the relative spot volumes, was used. By using this binary annotation for PCF instead of measured continuous values for relative spot volumes, the multivariate model was improved (data not shown). The reason for this was due to difficulties in the quantification of some of the major proteins in the rennet casein fraction, caused by some of the casein spots being very abundant. This complicated the quantification of the silver-stained caseins, a staining which has a relatively low dynamic range (Lopez et al., 2000). Therefore, the PLS-model for the PCF was selected only to indicate whether presence of a particular protein in the casein fraction had an effect on the cheese yield or not. When analyzing the effect of PWF on the cheese yield, however, the range of protein spots was more evenly distributed within the 2-DGE gels, and the relative spot volumes could be used.

The results from the regression analyses are presented in Tables 2 and 3. Using one principal component, PCF explained $63 \%$ of the total variation in cheese yield expressed as $\mathrm{g}$ of cheese per $100 \mathrm{~g}$ of milk (GCM), whereas $58 \%$ of the total variation in cheese yield expressed as g of dry cheese solids per $100 \mathrm{~g}$ of milk protein (GDMP) was explained by 2 principal components (Table 2). With 2 and 1 principal components, respectively, PWF explained 92 and $52 \%$ of the total variation in the same traits, respectively (Table 3 ). All of the PCF (23 spots) that were significant for GDMP had positive effects on this trait (Table 2), whereas significant PWF had positive (3 spots) and negative (4 spots) effects (Table 3 ). This showed that a range of protein spots in the rennet casein fraction 
Table 2. Significant weighted regression coefficients between proteins in the casein fraction (PCF) and the cheese yield (expressed in 2 ways)

\begin{tabular}{|c|c|c|}
\hline Spot ID ${ }^{1}$ & $\begin{array}{l}\mathrm{g} \text { of cheese per } 100 \mathrm{~g} \text { of milk } \\
{\left[1 \mathrm{PC}^{2} \text { explains } 63 \% \text { of the total }\right.} \\
\left.\text { variation in } \mathrm{Y}\left(\mathrm{R}^{2}=0.63\right)\right]\end{array}$ & $\begin{array}{l}\mathrm{g} \text { of dry cheese solids per } 100 \mathrm{~g} \text { of } \\
\text { milk protein }[2 \mathrm{PC} \text { explain } 58 \% \text { of the } \\
\left.\text { total variation in } \mathrm{Y}\left(\mathrm{R}^{2}=0.58\right)\right]\end{array}$ \\
\hline 5 & & $0.045^{*}$ \\
\hline 7 & & $0.040^{*}$ \\
\hline 11 & & $0.038^{* *}$ \\
\hline 13 & & $0.035^{* *}$ \\
\hline 14 & & $0.033^{*}$ \\
\hline 26 & & $0.037^{*}$ \\
\hline 38 & & $0.033^{* * *}$ \\
\hline 40 & & $0.028^{* *}$ \\
\hline 51 & & $0.027 * *$ \\
\hline 54 & & $0.025^{* *}$ \\
\hline 57 & & $0.021^{*}$ \\
\hline 64 & & $0.026^{*}$ \\
\hline 65 & & $0.025^{*}$ \\
\hline 76 & $0.060^{*}$ & $0.025^{*}$ \\
\hline 77 & & $0.027^{*}$ \\
\hline 78 & & $0.028^{* *}$ \\
\hline 84 & & $0.029^{* *}$ \\
\hline 85 & $0.057^{*}$ & $0.027 * *$ \\
\hline 91 & $-0.048^{*}$ & $0.039 * * *$ \\
\hline 101 & $0.051^{*}$ & \\
\hline \multicolumn{3}{|l|}{110} \\
\hline 119 & $0.066^{*}$ & $0.032 *$ \\
\hline \multicolumn{3}{|l|}{123} \\
\hline 132 & & $0.028^{* *}$ \\
\hline 136 & $-0.077^{*}$ & $0.034^{* *}$ \\
\hline \multicolumn{3}{|l|}{201} \\
\hline 258 & & $0.028^{* *}$ \\
\hline
\end{tabular}

${ }^{1}$ Spot identification (ID) in 2-dimensional gel electrophoresis.

${ }^{2} \mathrm{PC}=$ principal component. $\mathrm{R}^{2}$ is the correlation coefficient between measured and predicted y variables. ${ }^{*} P<0.05,{ }^{* *} P<0.01,{ }^{* * *} P<0.001$.

were positively associated with the transfer of proteins from milk to cheese. Looking at cheese yield expressed as GCM, 4 PCF (Table 2) and 17 PWF (Table 3) were positively associated with this trait, whereas $2 \mathrm{PCF}$ (Table 2) and 6 PWF (Table 3) were negatively associated with this type of cheese yield.

\section{Identified PCF}

The positions in a 2-DGE gel of the pinpointed PCF significant for cheese yield expressed as GCM or GDMP are presented in Figure 1. Most of the identified PCF corresponded to minor proteins or protein fragments with apparent significance for the cheese yield, and not to intact, major caseins. This was expected due to the use of a discriminant PLS-model, as mentioned above (i.e., a model that does not take into account the intensity of the spot, but whether it is present or not). A further reason for this is the fact that chymosin, which was added, not only cleaves the well-known $\mathrm{Phe}_{105}$ -Met ${ }_{106}$ bond in $\mathrm{k}-\mathrm{CN}$, but also cleaves a range of other peptide bonds on the casein molecules, especially in $a_{\mathrm{s} 1}$-CN (McSweeney et al., 1993, 1995).
The range of individual rennet caseins or sweet whey proteins that were significantly associated with any of the 2 types of cheese yield was aimed for identification by MALDI-TOF or Q-TOF mass spectrometry. Of the 23 spots in PCF of significance for cheese yield expressed as GDMP, 12 individual proteins could be identified by MS, as shown in Tables 4 and 5 and indicated in Figure 1. Four of the identified PCF corresponded to different forms of $\mathrm{a}_{\mathrm{s} 2}$ - CN, with spot identifications (ID) $26,38,54$, and 119 , all with positive effect on this type of yield. The identification of spot ID 26, as $\mathrm{a}_{\mathrm{s} 2}-\mathrm{CN}$, is in accordance with the position of intact $\mathrm{a}_{\mathrm{s} 2}-\mathrm{CN}$ reported earlier (Holland et al., 2004). In contrast to spot 26, spots 38, 54, and 119 all had lower molecular mass and a higher $\mathrm{pI}$ compared with intact $\mathrm{a}_{\mathrm{s}^{2}} \mathrm{CN}$ and thus represent proteolysis products of $\alpha_{\mathrm{s} 2}-\mathrm{CN}$, probably by chymosin or some indigenous milk enzyme (like, for example, plasmin). Chymosin has been reported to cleave $\mathrm{a}_{\mathrm{s} 2}$-casein at 8 sites in the hydrophobic regions of the molecule (McSweeney et al., 1994). Regardless of the type of enzyme, these cleavage products corresponded to larger protein fragments in the PCF, which thereby could explain their positive association with the cheese 
Table 3. Significant weighted regression coefficients between proteins in the whey protein fraction (PWF) and cheese yield (expressed in 2 ways)

\begin{tabular}{|c|c|c|}
\hline Spot ID ${ }^{1}$ & $\begin{array}{l}\mathrm{g} \text { of cheese per } 100 \mathrm{~g} \text { of milk } \\
{\left[2 \mathrm{PC}^{2} \text { explain } 92 \% \text { of the total }\right.} \\
\left.\text { variation in } \mathrm{y}\left(\mathrm{R}^{2}=0.92\right)\right]\end{array}$ & $\begin{array}{l}\mathrm{g} \text { of dry cheese solids per } 100 \mathrm{~g} \text { of milk } \\
\text { protein }[1 \text { PC explains } 52 \% \text { of the } \\
\left.\text { total variation in } \mathrm{y}\left(\mathrm{R}^{2}=0.52\right)\right]\end{array}$ \\
\hline 53 & $0.052^{*}$ & \\
\hline 57 & & $0.052^{*}$ \\
\hline 116 & -0.069 & \\
\hline 128 & $-0.045^{*}$ & \\
\hline 166 & $0.042^{*}$ & \\
\hline 210 & $-0.053^{*}$ & \\
\hline 211 & $0.049^{*}$ & \\
\hline 213 & $0.066^{*}$ & $0.051^{*}$ \\
\hline 231 & $0.062^{*}$ & \\
\hline 267 & $0.057^{*}$ & \\
\hline 268 & $0.041^{*}$ & \\
\hline 271 & $0.069^{*}$ & \\
\hline 282 & $0.050^{*}$ & \\
\hline 286 & $-0.056^{*}$ & \\
\hline 347 & $0.045^{*}$ & \\
\hline 359 & $0.052^{*}$ & \\
\hline 383 & $0.094^{* *}$ & \\
\hline 409 & & $-0.046^{*}$ \\
\hline 496 & $0.058^{* *}$ & \\
\hline 497 & $0.066^{*}$ & \\
\hline 538 & & $-0.069 *$ \\
\hline 545 & 0.058 & \\
\hline 546 & & -0.064 \\
\hline 559 & $-0.069^{*}$ & \\
\hline 567 & $0.054^{*}$ & \\
\hline 609 & & $-0.051^{*}$ \\
\hline 621 & & $0.079^{*}$ \\
\hline 639 & $-0.056^{* *}$ & \\
\hline 648 & $0.041^{* *}$ & \\
\hline
\end{tabular}

${ }^{1}$ Spot identification (ID) in 2-dimensional gel electrophoresis.

${ }^{2} \mathrm{PC}=$ principal component. $\mathrm{R}^{2}$ is the correlation coefficient between measured and predicted y variables. ${ }^{*} P<0.05 ;{ }^{*} P<0.01$.

yield (i.e., these fragments would not appear on the gel if they were further degraded). Further identified spots of significance for GDMP included spot number 40, 51 and 57, which were found to contain B-CN. These B-CN forms most probably corresponded to different phosphorylated forms and perhaps also genetic variants of B-CN. However, the degree of phosphorylation or the exact amino acid sequences could not be verified from the identification method used.

Among the range of minor spots found to be positively associated with GDMP (Figure 1 and Table 2) 4 spots with ID $64,65,78$, and 85 were identified by MS to contain $\alpha_{\mathrm{s} 1}-\mathrm{CN}$. As they were located in a region below the position of the intact $\alpha_{\mathrm{s} 1}-\mathrm{CN}$ cluster (Figure 1), at positions corresponding to lower molecular masses than intact $\mathrm{a}_{\mathrm{s} 1}-\mathrm{CN}$, these spots corresponded to proteolysis products of $\mathrm{a}_{\mathrm{s} 1}-\mathrm{CN}$, probably by chymosin. Chymosin is known to cleave $\mathrm{a}_{\mathrm{s} 1}-\mathrm{CN}$ at several sites, initially to $\alpha_{\mathrm{s} 1}-\mathrm{I}$ (f25 to 199) and later to $\alpha_{\mathrm{s} 1}$-II (f25 to 169) and further products (Fox, 1988). Protein spot ID 5 , in the casein fraction, corresponded to BSA (Figure 1) and was positively associated with cheese yield expressed as GDMP (Table 2). The presence of minor whey proteins in the casein fraction most probably confirms that some whey proteins were entrapped in the precipitated caseins formed after cleavage by chymosin. The fact that BSA was significant for GDMP (i.e., the protein transition number) would imply that a higher amount of the whey proteins were entrapped in the cheese and thereby increased the transfer of total protein from milk to cheese.

Further spots in the PCF of significance for cheese yield expressed as GCM included spot ID 110, which had a positive effect. This spot contained B-CN, and due to its location far below the position of intact B-CN (Figure 2), this spot corresponded to a fragment of B-CN generated probably by chymosin, or eventually an indigenous milk protease. The peptide mass fingerprinting obtained from this spot were composed of peptides derived from positions 107 to 209 in the $8-\mathrm{CN}$ molecule, whereas no peptides were identified from the $\mathrm{N}$-terminal part of the molecule. This indicated that this B-CN fragment was the result of a proteolytic cleavage in the N-terminal part of the B-CN molecule. 
Table 4. Proteins from the rennet casein or the sweet whey fraction with significant effects on cheese yield identified by matrix-assisted laser desorption time-of-flight (MALDI-TOF) or tandem (MS/MS) mass spectrometry

\begin{tabular}{|c|c|c|c|c|c|c|}
\hline Spot ID & Protein & $\begin{array}{l}\text { Sequence } \\
\text { coverage }^{1}\end{array}$ & Matched peptides $^{2}$ & $\begin{array}{c}\text { Theo. } \\
\mathrm{pI}^{3}\end{array}$ & $\begin{array}{l}\text { Theo. } \mathrm{Mw}^{4} \\
\text { (kDa) }\end{array}$ & $\begin{array}{l}\text { SWISS-PROT } \\
\text { access key }\end{array}$ \\
\hline \multicolumn{7}{|c|}{ Casein fraction } \\
\hline 5 & BSA & 22 & 11 & 5.8 & 71 & P02769 \\
\hline 38 & $\mathrm{a}_{\mathrm{s} 2}-\mathrm{CN}$ & 23 & & 4.6 & 26 & P02663 \\
\hline 54 & $\mathrm{a}_{\mathrm{s} 2}-\mathrm{CN}$ & 20 & & 4.6 & 26 & P02663 \\
\hline 119 & $\mathrm{a}_{\mathrm{s} 2}-\mathrm{CN}$ & 32 & 11 & 4.6 & 26 & P02663 \\
\hline 116 & Vitamin D-binding protein & 34 & 15 & 5.2 & 55 & Q3MHN5 \\
\hline 210 & B-LG & 43 & 7 & 4.8 & 20 & P02754 \\
\hline 211 & B-LG & 41 & 8 & 4.8 & 20 & P02754 \\
\hline 213 & B-LG & 54 & 8 & 4.8 & 20 & P02754 \\
\hline 409 & $a-L A$ & 34 & 5 & 4.9 & 17 & P00711 \\
\hline 567 & $a-L A$ & 43 & 8 & 4.9 & 17 & P00711 \\
\hline 609 & BSA & 16 & 8 & 5.8 & 71 & P02769 \\
\hline
\end{tabular}

${ }^{1}$ The minimum coverage of the matched peptides in relation to the full-length sequence.

${ }^{2}$ The number of matched peptides in the database search.

${ }^{3}$ Theoretical pI of the full-length protein.

${ }^{4}$ Theoretical molecular mass (Mw) of the full length protein.

${ }^{5}$ Primary accession key in the SWISS-PROT database.

${ }^{6}$ The protein was identified by MS/MS of the parent $\alpha_{\mathrm{s} 2}$-casein ion $1,367.696 \mathrm{~m} / \mathrm{z}$.

The positive regression between this B-CN fragment and cheese yield is interesting, but the background for this is not known and would require further studies.

\section{Identified PWF}

The locations of PWF significant for the cheese yield in a 2-DGE gel of separated whey proteins are presented in Figure 2. In addition to the major B-LG spot of native molecular mass located in the lower region of the 2-DGE gel (spot ID 359) that had a positive effect on GCM (Table 3 and Figure 2), 2 other spots containing B-LG were identified by MS (Table 4). These had significant effects on cheese yield expressed as GCM, one negatively (spot ID 210) and one positively (spot ID 211) and probably corresponded to complexes containing $B-\mathrm{LG}$, due to their higher molecular masses as compared with the major B-LG spot. The B-LG variant being negatively associated with cheese yield (spot ID 210) appeared at a lower pI on the 2-DGE gel (Figure 2 ). It is very likely that this protein spot corresponded to the A-variant of B-LG, which due to an extra aspartic acid, has a more negative net charge compared with the B-variant. It was not possible, however, to derive this from the MS data because the relevant peptides covering these amino acids were not included in the peptide mass finger printings. In the present study, a third variant of B-LG (spot ID 213, Tables 3 and 4 and Figure 2) had a positive effect on the cheese yield expressed as GDMP. This variant most probably cor- responded to a modification product of $B-L G B$, which has a more positive net charge compared with the Avariant. Most likely, also the major B-LG spot (spot ID 359) corresponded to the B-variant of B-LG, which in earlier findings was found to be positively associated with both types of cheese yield (Wedholm et al., 2006).

Two different spots, identified by MS as a-LA, were significantly associated with cheese yield; one was negatively associated with GDMP (spot ID 409; Table 3 and Figure 2), whereas one was positively associated with GCM (spot ID 567). It is possible that these forms of a-LA may represent different glycosylated forms of a-LA because a minor part of the molecule is glycosylated, of which some forms contain the negatively charged sialic acid (Slangen and Visser, 1999), but this was not further studied. Of the identified minor whey proteins, lactoferrin (spot ID 57) was positively associated with GDMP, whereas BSA (spot ID 609) was negatively associated with the same trait. The latter is in agreement with the results from the casein separation (i.e., the presence of BSA in the rennet casein fraction was found to have a positive impact on GDMP). Lactoferrin identified in spot ID 57 had a lower pI compared with the theoretical pI for the full length protein (Table 4 and Figure 2). Pepsin is known to split off a fragment of 25 amino acids from lactoferrin, known as lactoferricin (Yamauchi et al., 1993), and it is possible that chymosin is responsible for this cleavage too. Furthermore, spot ID 116 (identified as vitamin-D binding protein, Table 4) and spot ID 286 (immunoglobulin G $\lambda$-light chain, 
Table 5. Proteins from the rennet casein or the sweet whey fraction with significant effects on cheese yield identified by electrospray quadropole time-of-flight (Q-TOF) tandem mass spectrometry (MS/MS)

\begin{tabular}{|c|c|c|c|c|c|c|}
\hline Spot ID & Protein & $\begin{array}{l}\text { Sequence } \\
\text { coverage }^{1}\end{array}$ & $\begin{array}{l}\text { Unique MS/ } \\
\text { MS queries }^{2}\end{array}$ & $\begin{array}{c}\text { Theo. } \\
\mathrm{pI}^{3}\end{array}$ & $\begin{array}{l}\text { Theo. } \mathrm{Mw}^{4} \\
\text { (kDa) }\end{array}$ & $\begin{array}{l}\text { Access } \\
\text { key }\end{array}$ \\
\hline \multicolumn{7}{|c|}{ Casein fraction } \\
\hline 38 & $\mathrm{a}_{\mathrm{s} 2}-\mathrm{CN}$ & 38 & 10 & 4.60 & 26 & $\mathrm{P} 02663^{5}$ \\
\hline 40 & $\mathrm{~B}-\mathrm{CN}$ & 9 & 3 & 5.13 & 23 & P02666 ${ }^{5}$ \\
\hline 51 & $\mathrm{~B}-\mathrm{CN}$ & 35 & 13 & 5.13 & 23 & $\mathrm{P} 02666^{5}$ \\
\hline 54 & $\mathrm{a}_{\mathrm{s} 2}-\mathrm{CN}$ & 25 & 5 & 4.60 & 26 & $\mathrm{P} 02663^{5}$ \\
\hline 57 & $\mathrm{~B}-\mathrm{CN}$ & 55 & 18 & 5.13 & 23 & $\mathrm{P} 02666^{5}$ \\
\hline 64 & $\mathrm{a}_{\mathrm{s} 1}-\mathrm{CN}$ & 49 & 15 & 4.90 & 23 & $\mathrm{P} 02662^{5}$ \\
\hline 65 & $\mathrm{a}_{\mathrm{s} 1}-\mathrm{CN}$ & 28 & 6 & 4.90 & 23 & $\mathrm{P} 02662^{5}$ \\
\hline 78 & $\mathrm{a}_{\mathrm{s} 1}-\mathrm{CN}$ & 31 & 6 & 4.90 & 23 & $\mathrm{P} 02662^{5}$ \\
\hline 85 & $\mathrm{a}_{\mathrm{s} 1}-\mathrm{CN}$ & 35 & 7 & 4.90 & 23 & $\mathrm{P} 02662^{5}$ \\
\hline 110 & $\mathrm{~B}-\mathrm{CN}$ & 26 & 19 & 5.13 & 23 & $\mathrm{P} 02666^{5}$ \\
\hline 119 & $\mathrm{a}_{\mathrm{s} 2}-\mathrm{CN}$ & 60 & 17 & 4.60 & 26 & $\mathrm{P} 02663^{5}$ \\
\hline \multicolumn{7}{|c|}{ Whey fraction } \\
\hline 282 & IgG $\lambda$-light chain & 37 & 15 & 7.53 & 24 & $15088675^{6}$ \\
\hline 286 & IgG $\lambda$-light chain & 62 & 22 & 7.53 & 24 & $15088675^{6}$ \\
\hline
\end{tabular}

${ }^{1}$ The minimum coverage of the matched peptides in relation to the full-length sequence.

${ }^{2}$ The number of unique matched peptides in the database search.

${ }^{3}$ Theoretical pI of the full length protein.

${ }^{4}$ Theoretical molecular mass (Mw) of the full length protein.

${ }^{5}$ Primary accession key in the SwissProt database.

${ }^{6}$ Primary accession key in the NCBInr database.

Table 5) were negatively associated with cheese yield expressed as GCM. However, the explanations for the significant regressions between lactoferrin, vitamin-D binding protein, or immunoglobulin $\mathrm{G} \lambda$-light chain and cheese yield is not known.

Each of the identified PCF or PWF had a low individual effect on the cheese yield. It is possible, though, that a combination of all significant PCF and PWF could be used to predict cheese yield from the composition of chymosin separated whey and casein. It has to be stressed that the major caseins, which were not evaluated in this study, also contribute significantly to the variation in cheese yield (Wedholm et al., 2006) and therefore should be included in a prediction model. However, further studies on a more comprehensive material combined with cheese-making trials in full scale are needed to strengthen the results found in this study. To conclude whether chymosin is responsible for the casein cleavage products identified in this study, it would be relevant in a future study to compare 2-DGE pictures of chymosin-separated caseins with those of acid precipitated.

\section{CONCLUSIONS}

Several proteins in either the rennet casein or the sweet whey fractions had positive or negative effects $(P<0.05)$ on the yield of model cheeses made from the individual milk samples. In the rennet casein fraction, several protein spots were found to have positively significant effects on cheese yield expressed as GDMP. Some of these spots were identified, by MS, to contain different fragments of $\mathrm{a}_{\mathrm{s} 1^{-}}, \mathrm{a}_{\mathrm{s} 2^{-}}$, and B-CN. Among the proteins in the rennet casein fraction that had positively significant effects on cheese yield, expressed as GCM, a specific B-CN fragment was identified. In the sweet whey fraction, several whey proteins had either positive or negative effects $(P<0.05)$ on the cheese yield. Of the major whey proteins identified, a spot containing B-LG had a positive effect on GCM and was concluded to be B-LG B. Further identified significant whey proteins included a-lactalbumin, lactoferrin, vitamin D-binding protein, immunoglobulin $\mathrm{G} \lambda$-light chain, and BSA. The explanations for associations between these proteins and the cheese yield are not yet fully understood.

\section{ACKNOWLEDGMENTS}

The authors wish to thank Helle Louise Christensen, Stina Greis Handberg, and Rita Albrechtsen, Department of Food Science, Faculty of Agricultural Sciences, University of Aarhus, for excellent technical assistance, and John Sørensen, Head of Research Unit, Department of Food Science, Faculty of Agricultural Sciences, University of Aarhus, for critically reading the manuscript. The Danish Research Foundation, the Innovation law, and the Swedish Farmer's Foundation for Agricultural Research are gratefully acknowledged for the financial support. 


\section{REFERENCES}

Allmere, T., A. Andrén, M. Lindersson, and L. Björck. 1998. Studies on rheological properties of stirred milk gels made from milk with defined genetic variants of $\mathrm{k}$-casein and B-lactoglobulin. Int. Dairy J. 8:899-905.

Bansal, N., P. F. Fox, and P. L. H. McSweeney. 2007. Factors affecting the retention of rennet in cheese curd. J. Agric. Food Chem. 55:9219-9225.

Emmons, D. B. 1993. Definition and expression of cheese yield. In Factors Affecting the Yield of Cheese. D. B. Emmons, ed. Int. Dairy Fed., Belgium.

Emmons, D. B., C. Dube, and H. W. Modler. 2003. Transfer of protein from milk to cheese. J. Dairy Sci. 86:469-485.

Fong, B. Y., C. S. Norris, and K. P. Palmano. 2008. Fractionation of bovine whey proteins and characterisation by proteomic techniques. Int. Dairy J. 18:23-46.

Fox, P. F. 1988. Rennets and their action in cheese manufacture and ripening. Biotechnol. Appl. Biochem. 10:522-535.

Galvani, M., M. Hamdan, and P. G. Righetti. 2000. Two-dimentional gel electrophoresis/matrix-assisted laser desorption/ionisation mass spectrometry of a milk powder. Rapid Commun. Mass Spectrom. 14:1889-1897.

Galvani, M., M. Hamdan, and P. G. Righetti. 2001. Two-dimentional gel electrophoresis/matrix-assisted laser desorption/ionisation mass spectrometry of commercial bovine milk. Rapid Commun. Mass Spectrom. 15:258-264.

Gottlieb, D. M., J. Schultz, S. W. Bruun, S. Jacobsen, and I. S. Øndergaard. 2004. Multivariate approaches in plant science. Phytochemistry 65:1531-1548.

Holland, J. W., H. C. Deeth, and P. F. Alewood. 2004. Proteomic analysis of K-casein micro-heterogeneity. Proteomics 4:743752.

Ikonen, T., K. Ahlfors, R. Kempe, M. Ojala, and O. Ruottinen. 1999. Genetic parameters for the milk coagulation properties and prevalence of noncoagulating milk in Finnish dairy cows. J. Dairy Sci. 82:205-214.

Jensen, O. N., M. R. Larsen, and P. Roepstorff. 1998. Mass spectrometric identification and microcharacterization of proteins from electrophoretic gels: Strategies and applications. Proteins 2:74-89.

Jessen, F., R. Lametsch, E. Bendixen, I. V. H. Kjærsgård, and B. M. JØrgensen. 2002. Extracting information from two-dimensional electrophoresis gels by partial least squares regression. Proteomics 2:32-35.

Lametsch, R., and E. Bendixen. 2002. Proteome analysis applied to meat science: Characterizing post mortem changes in porcine muscle. J. Agric. Food Chem. 49:4531-4537.

Lametsch, R., P. Roepstorff, and E. Bendixen. 2002. Identification of protein degradation during post mortem storage of pig meat. J. Agric. Food Chem. 50:5508-5512.

Larsen, L. B., A. Wedholm, H. S. M. Øller, H. Lindmark-Månsson, and A. Andrén. 2007. Proteomic study of regressions between milk yield and whey protein composition. J. Anim. Feed Sci. 1:200-206.

Lindmark-Månsson, H., A. Timgren, G. Aldén, and M. Paulsson. 2005. Two-dimentional gel electrophoresis of proteins and peptides in bovine milk. Int. Dairy J. 15:111-121.

Lopez, M. F., K. Berggren, E. Chemkalskaya, A. Lazarev, M. Robinson, and W. F. Patton. 2000. A comparison of silver stained and SYPRO Ruby protein gel stain with respect to protein detection in two-dimensional gels and identification by peptide mass profiling. Electrophoresis 21:3673-3683.

Lundén, A., M. Nilsson, and L. Janson. 1997. Marked effect of B-lactoglobulin polymorphism on the ratio of casein to total protein in milk. J. Dairy Sci. 80:2996-3005.

Martens, H., and M. Martens. 2000. Modified jack-knife estimation of parameter uncertainty in bilinear modelling by partial least squares regression (PLSR). Food Qual. Prefer. 11:5-16.

Marziali, A. S., and K. F. Ng-Kwai-Hang. 1986. Relationships between milk protein polymorphisms and cheese yielding capacity. J. Dairy Sci. 69:1193-1201.

McSweeney, P. L. H., P. F. Fox, and N. F. Olson. 1995. Proteolysis of bovine caseins by Cathepsin-D-Preliminary observations and comparison with chymosin. Int. Dairy J. 5:321-336.

McSweeney, P. L. H., N. F. Olson, P. F. Fox, H. Healy, and P. H. Øjrup. 1993. Proteolytic specificity of chymosin on bovine $\alpha_{s 1^{-}}$ casein. J. Dairy Res. 60:401-412.

McSweeney, P. L. H., N. F. Olsson, P. F. Fox, and A. Healy. 1994 Proteolysis of bovine $\alpha_{\mathrm{s} 2}$-casein by chymosin. Zeitsch. Lebensm. Forsch. A 199:429-432.

Ng-Kwai-Hang, K. F. 1998. Genetic polymorphism of milk proteins: Relationships with production traits, milk composition and technological properties. Can. J. Anim. Sci. 78(Supplement):131-147.

O'Donnell, R., J. W. Holland, H. C. Deeth, and P. Alewood. 2004. Milk proteomics. Int. Dairy J. 14:1013-1023.

Paris Publication Guidelines. 2007. http://www.mcponline.org/misc/ ParisReport_Final.shtml Accessed Dec. 13, 2007.

Radzikowski, L., L. Nesic, H. B. Hansen, S. Jacobsen, and I. S. Øndergard. 2002. Comparison of ethanol-soluble proteins from different rye (Secale cereale) varieties by two-dimensional electrophoresis. Electrophoresis 23:4157-4166.

Schaar, J., B. Hansson, and H. E. Pettersson. 1985. Effects of genetic variants of $\mathrm{K}$-casein and B-lactoglobulin on cheesemaking. J. Dairy Res. 52:429-437.

Shevchenko, A., M. Wilm, O. Vorm, and M. Mann. 1996. Mass spectrometric sequencing of proteins from silver stained polyacrylamide gels. Anal. Chem. 68:850-858.

Slangen, C. J., and S. Visser. 1999. Use of mass spectrometry to rapidly characterize the heterogeneity of bovine a-lactalbumin. J. Agric. Food Chem. 47:4549-4556.

Smolenski, G., S. Haines, F. Y. S. Kwan, J. Bond, V. Farr, S. Davis, K. Stelwagen, and T. T. Wheeler. 2002. Characterisation of host defence proteins in milk using a proteomic approach. J. Proteome Res. 6:207-215.

van den Berg, G., J. T. M. Escher, P. J. de Koning, and H. Bovenhuis. 1992. Genetic polymorphism of $\mathrm{K}$-casein and B-lactoglobulin in relation to milk composition and processing properties. Neth. Milk Dairy J. 46:145-168.

Wedholm, A., L. B. Larsen, H. Lindmark-Månsson, A. H. Karlsson, and A. Andrén. 2006. Effect of protein composition on the cheesemaking properties of milk from individual dairy cows. J. Dairy Sci. 89:3296-3305.

Yamada, M., K. Murakami, J. C. Wallingford, and Y. Yuki. 2002. Identification of low-abundance proteins of bovine colostral and mature milk using two-dimensional electrophoresis followed by microsequencing and mass spectrometry. Electrophoresis 23:1153-1160.

Yamauchi, K., M. Tomita, T. J. Giehl, and R. T. Ellison. 1993. Antibacterial activity of lactoferrin and a pepsin-derived lactoferrin peptide fragment. Infect. Immun. 61:719-728. 